\title{
PENERAPAN TEKNOLOGI BIOPORI UNTUK MENINGKATKAN KETERSEDIAN AIR TANAH SERTA MENGURANGI SAMPAH ORGANIK DI DESA PURON SUKOHARJO
}

\author{
Zainal Arifin*1, Dominicus Danardono Dwi Prija Tjahjana ${ }^{1}$, Rendy Adhi Rachmanto ${ }^{1}$, Suyitno ${ }^{1}$, \\ Singgih Dwi Prasetyo ${ }^{1}$, Syamsul Hadi ${ }^{1}$ \\ ${ }^{1}$ Program Studi Teknik Mesin, Fakultas Teknik, Universitas Sebelas Maret, Surakarta \\ *Email: zainal_arifin@staff.uns.ac.id
}

\begin{abstract}
Abstrak
Ketersediaan air tanah di Desa Puron Kecamatan Bulu Kabupaten Sukoharjo semakin menurun. Hal itu dikarenakan pengambilan air tanah yang tidak diimbangi dengan semangat konservasi dan sedikitnya air hujan yang masuk ke dalam tanah. Berkurangnya jumlah air yang ada mengakibatkan mengeringnya tumbuhan di lingkungan tersebut. Selain itu, masih banyaknya sampah rumah tangga menjadi permasalahan yang harus dihadapi masyarakat permukiman. Penanganan sampah dan irigasi secara konvensional yang telah diterapkan oleh masyarakat belum menjadi solusi terbaik. Sehingga perlu penanganan secara tersistematis, terstruktur dan berkelanjutan. Pengabdian yang dilakukan bertujuan untuk membantu masyarakat Desa Puron dalam menangani masalah air dan sampah. Pengabdian masyarakat dengan mensosialisasikan dan mengajak masyarakat untuk melakukan konservasi sumber daya air dengan penerapan teknologi sederhana dan murah. Penerapan teknologi yang bisa diterapkan yaitu dengan pembuatan lubang resapan biopori untuk meningkatkan jumlah air dalam tanah serta mengurangi sampah organik di Desa Puron. Lubang resapan biopori berfungsi sebagai tempat resapan air ke dalam tanah dan sebagai tempat pembuatan kompos dari sampah organik. Lubang resapan biopori tidak membutuhkan area luas dan proses pembuatannya sangat mudah, hal ini tentu menjadi solusi yang tepat untuk wilayah Desa Puron. Hasil pengabdian menjadikan ketersedian air yang ditandai dengan menghijaunya tumbuhan.
\end{abstract}

Kata kunci: Air, Biopori, Pengabdian, Desa Puron

\section{Pendahuluan}

Desa Puron merupakan salah satu Desa di bagian selatan Kabupaten Sukoharjo, Provinsi Jawa Tengah. Kondisi dan letak geografis Desa mempengaruhi terhadap curah hujan yang ada di daerah Indonesia (Mulyono, 2014). Sedikitnya intensitas hujan di Desa Puron menjadikan sedikitnya air yang terserap ke tanah. Kondisi tanah yang kering juga menyebabkan ketersediaan air tanah yang semakin menurun (Kusumawati et al., 2008). Krisis air ini menyebabkan jumlah air yang tersedia di akuifer atas cekungan air tidak mencukupi terhadap kebutuhan pemakaian air di masyarakat (Sedana et al., 2015). Sedikitnya air yang tersedia juga menyebabkan tumbuhan cepat mati dan pertanian menjadi kurang menarik untuk dikembangkan di daerah tersebut (Sinaga, 2008). 
Kelompok mitra telah berusaha untuk membuat penghijauan di lahan-lahan tandus khususnya kas desa yang ada di perbukitan desa Puron. Usaha ini belum berhasil meningkatkan fungsi lahan dan perekonomian masyarakat. Beberapa penyebab yang didalami berdasarkan survey tim pengabdi di lapangan adalah: (a) ketersediaan air tanah yang semakin berkurang. Keberadaan pamsimas menyebabkan debit air tanah semakin berkurang khususnya pada musim kemarau. (b) ketiadaan daerah resapan yang ditandai dengan keringnya pepohonan di musim kemarau. (c) kualitas tanah yang gersang sehingga tanaman hijau sulit tumbuh, sebagaimana Gambar 1.

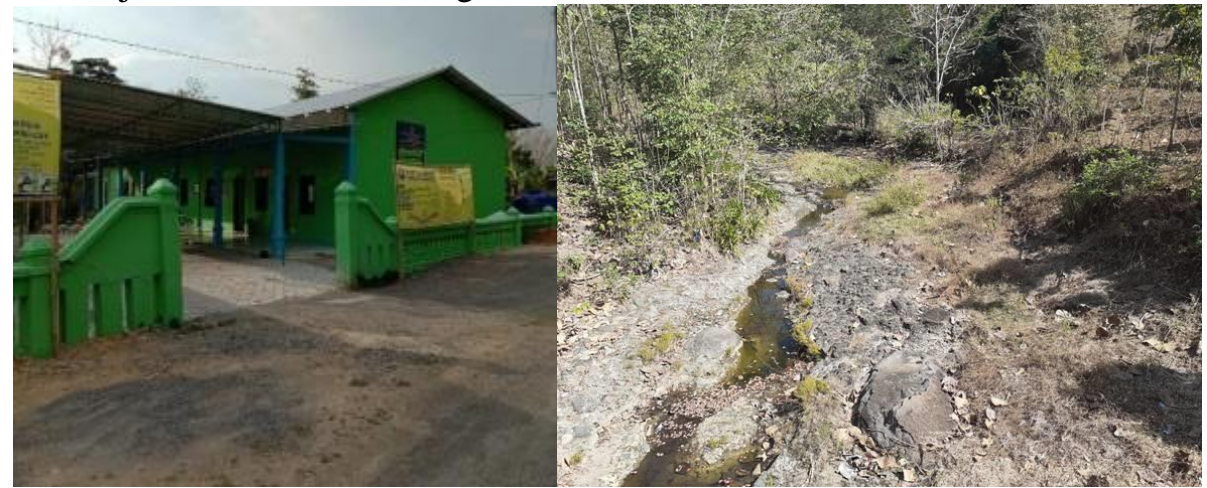

(a)

(b)

Gambar 1. (a) Lokasi (b) Tanah sekitar mitra

Sementara itu, masyarakat sekitar mitra masih mempunyai masalah lain yaitu penanganan sampah rumah tangga yang semakin menumpuk. Hal itu menyebabkan lingkungan sekitar terlihat kumuh dan kotor. Oleh karena itu, pengabdi menyarankan untuk memilahnya terlebih dahulu agar dapat kita manfaatkan. Sampah dipilah dengan sampah organik dijadikan kompos dan sampah anorganik dapat didaur ulang menjadi barang lain yang lebih bermanfaat (Bank et al., 2016). Akan tetapi, dalam proses pembuatan kompos organik masih terkendala dengan lahan yang digunakan dalam pengolahan dan kemungkinan timbulnya bau akibat proses composting (Widyastuty et al., 2019).

Program kemitraan masyarakat ini berupaya untuk mengatasi masalah mitra dengan dengan mensosialisasikan dan mengajak masyarakat untuk melakukan konservasi sumberdaya air dengan penerapan teknologi sederhana dan murah. Penerapan teknologi yaitu dengan pembuatan lubang resapan biopori. Konsep teknologi biopori merupakan salah satu langkah solutif untuk meningkatkan jumlah resapan air kedalam tanah. Ukuran serta dimensi lubang resapan tidak terlalu membutuhkan lahan yang besar. Hal itu dengan menyesuaikan luasan permukaan tertutup, karakteristik hujan, tinggi muka air tanah, dan volume dan efisiensi serapan tanah (Yohana et al., 2017). Untuk memperbaiki kualitas tanah penerapan teknologi biopori juga dapat dijadikan sebagai tempat pengolahan limbah sampah organik yang dapat dijadikan kompos organik (Karuniastuti, 2014). Sehingga permasalahan sampah pada mitra dapat terselesaikan dan tumbuhan dekat resapan mampu hidup di musim kemarau (Permana et al., 2019). Luaran yang menjadi prioritas dalam program kemitraan masyarakat ini adalah mitra mengetahui proses penerapan teknologi biopori untuk meningkatkan kualitas tanah dan resapan air tanah yang ditandai dengan menghijaunya kembali tumbuhan sekitar lingkungan mitra. 


\section{Metode Pelaksanaan}

Metode pelaksanaan kegiatan program kemitraan masyarakat dibagi beberapa tahapan kegiatan dan langkah-langkah untuk mengatasi permasalahan mitra. Secara umum, pengabdian menggunakan metode perancangan, sosialisasi, pembuatan, implementasi metode pembelajaran entreprenership berbasis teknologi biopori. Metode yang digunakan dalam peningkatan kualitas lingkungan melalui pelatihan dan pembuatan lubang resapan biopori melalui pendekatan partisipatori yaitu masyarakat dan tim pelaksana bersama-sama berperan aktif dalam kegiatan ini (Elsie et al., 2017). Hal ini bertujuan untuk meningkatkan kualitas lingkungan permukiman dan meningkatkan kesejahteraan masyarakat dalam pemecahan masalah yang di hadapi oleh mitra masyarakat di Desa Puron, Bulu, Sukoharjo, Jawa Tengah yang dipraktekkan langsung. Adapun tahapan pelaksanaan kegiatan ini dapat dilihat pada Gambar 2.

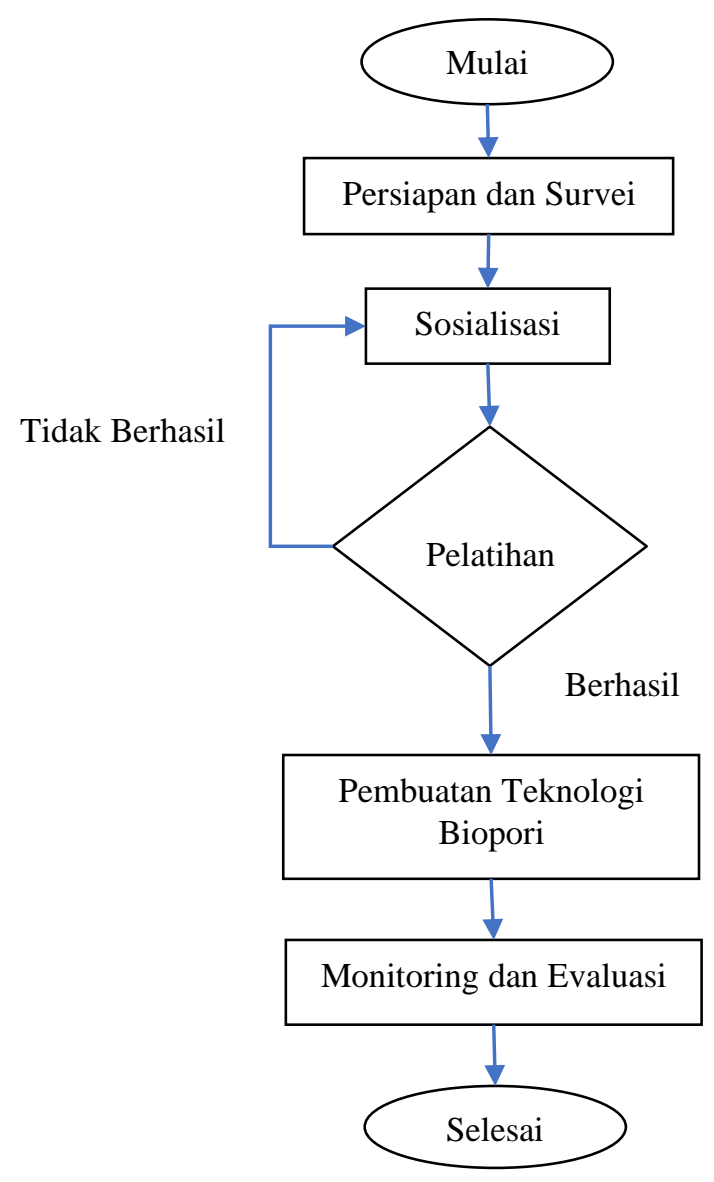

Gambar 2. Diagram alur pengabdian 


\section{Peran dan Tugas Pengabdi}

1. Tahap persiapan dan survey, yaitu melakukan identifikasi karakter lahan dan kondisi fisik lingkungan permukiman. Memetakan lahan-lahan terbuka baik di halaman rumah maupun di ruang terbuka yang ada di lingkungan permukiman yang potensial untuk dibuatkan lubang biopori. Kemudian menentukan target lokasi pembuatan biopori oleh masyarakat.

2. Sosisalisasi dengen menggunakan metode presentasi. Agar mitra masyarakat Desa Puron, Bulu, Sukoharjo, Jawa Tengah mengetahui, memahami dan lebih responsif memanfaatkan halaman rumahnya untuk lubang resapan air.

3. Tahap pelatihan pembuatan biopori, yaitu melakukan penyuluhan dan workshop mengenai pengenalan peralatan dan bahan material yang perlu disiapkan untuk pembuatan biopori, serta pelatihan pembuatan biopori secara berkelompok.

4. Tahap implementasi kegiatan pembuatan, biopori, yaitu melakukan pembuatan lubang lubang biopori di lingkungan permukiman, khususnya pada area-area yang telah dipilih dan disepakati bersama.

\section{Peran dan Tugas Mitra}

Partisipasi mitra sudah ada mulai dari awal kegiatan sosialisasi sampi akhir kegiatan berupa pembuatan biopori di lingkungan perumahan.

1. Tahap sosialisasi, partisipasi mitra berupa keikutsertaan dalam rapat, menyediakan tempat dan makanan dan minuman rapat. Sosialisasi gambar, kegiatan sosialisasi gambar dilakukan oleh mitra dalam hal ini adalah pengurus paguyuban dan pengurus RT.

2. Tahap Pembentukan Tim, tim yang dibentuk berasal dari warga (mitra) baik untuk tim perencana maupun tim pelaksana Perencanaan Tim perencana berasal dari warga (mitra) yang mempunyai latar belakang pendidikan teknik bangunan atau yang berpengalaman dalam perencanaanbiopori.

3. Pelatihan dalam pembuatan penerapan teknologi biopori agar masyarakat semakin mengerti arah dan tujuan pengabdian.

4. Pelaksanaan Pembuatan Biopori, tim pelaksana pembangunan merupakan warga ataupun dapat dibantu tukang/ tenaga bangunan dari luar wilayah RT.

\section{Evaluasi pelaksanaan pengabdian}

Melakukan evaluasi secara keseluruhan tentang keberhasilan program pengabdian dengan monitoring kegiatan pelaksanaan dan pendampingan. Penjadwalan waktu pengabdian serta memastikan semua proses dan tahapan pengabdian sesuai dengan mekanisme yang telah ditentukan. Analisa hasil dilakukan untuk keberlangsungan program, pelaporan dan evaluasi keberlanjutan program pengabdian.

\section{Hasil Dan Pembahasan}

Adapun hasil yang dicapai pada program kemitraan masyarakat dengan konsep biopori sebagai penanggulangan krisis air dan pemanfaatan sampah organik sebagai kompos dengan metode pelaksanaan sebagai berikut: 


\section{Identifikasi dan Sosialisasi}

Identifikasi dilakukan menggunakan metode survei, survei dilakukan di Desa Puron Bersama paguyuban pecinta lingkungan hidup. Identifikasi di lingkungan sekolah Desa, hal ini karena pengabdi melakukan sasaran utamanya kepada staff pengajar, siswa, dan pecinta llingkungan hidup agar menjadikan inisiasi untuk bisa menjadikan contoh untuk masyarakat sekitar. Identifikasi dilakukan pada bulan Juli tahun 2020 dengan pengabdi melakukan wawancara terhadap masyarakat sekitar. Selain itu, dilakukan pemetaan tempat yang akan dijadikan untuk pembuatan lubang resapan biopori sebagaimana Gambar 3 (Sedana et al., 2015).

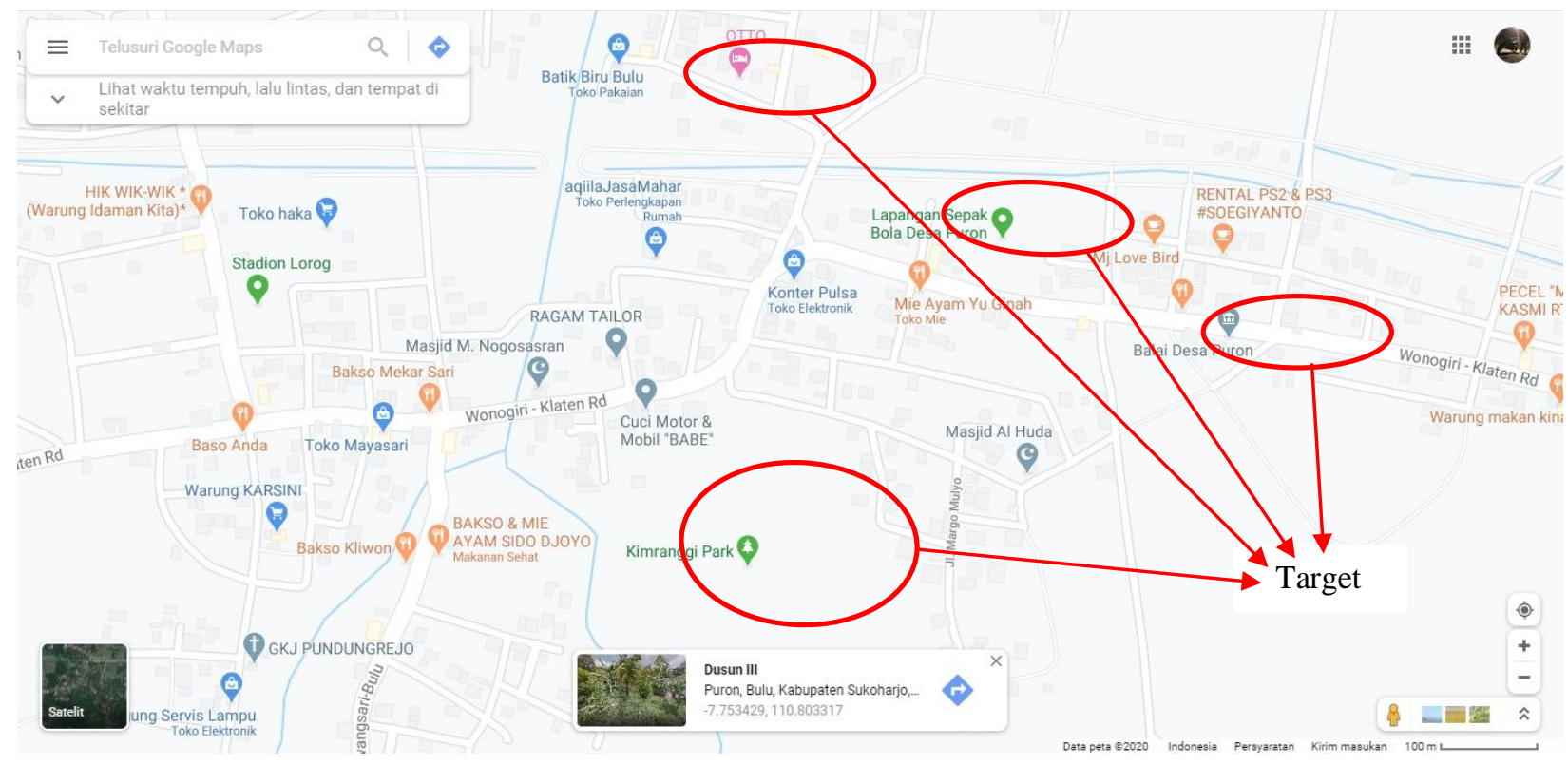

Gambar 3. Pemetaan lokasi target pembuatan lubang resapan biopori

Keterbatasan pengetahuan dan informasi masyarakat penanggulangan krisis air dan pemanfaatan kompos menjadi kendala dalam melakukan survei ini. Untuk menanggulangi permasalahan tersebut dilakukan sosialisasi penerapan teknologi biopori kepada masyarakat Desa Puron. Sosialisasi bertujuan meningkatkan pengetahuan dan informasi mengenari penerapan teknologi biopori (Permana et al., 2019). Materi sosialisasi dapat dilihat pada Tabel 1. Selain itu, menjadikan adanya peningkatan kapasitas masyarakat untuk aktif secara mandiri dalam melakukan konservasi lingkungan.

Tabel 1. Materi sosialisasi

\begin{tabular}{lllll}
\hline Waktu & Materi Pengabdian & Content/Outline & \multicolumn{2}{l}{ Keterangan } \\
\hline Minggu & Permasalahan & Konsep dasar, Definisi, Ruang & Pemateri: Tim Pelaksana \\
Pertama & Ketersedian Air dan & Lingkup, Dimensi, Sasaran: Masyarakat Desa \\
& Sampah. & Karakteristik, Peranan, & Puron \\
& & Urgensi, dan Implementasi & Metode: Ceramah dan \\
& & & Tanya Jawab & Waktu: Sabtu (08.00-11.00) \\
& & & Alat: Papan edukasi, \\
\hline
\end{tabular}


Jurnal SEMAR Vol. 9 No. 2, hal. $53-63$

eISSN: 2745-4223 | Copyright (C LPPM Universitas Sebelas Maret Homepage: https://jurnal.uns.ac.id/jurnal-semar

\begin{tabular}{|c|c|c|c|}
\hline & & & handout, laptop \\
\hline \multirow{7}{*}{$\begin{array}{l}\text { Minggu } \\
\text { Kedua }\end{array}$} & Penerapan & Konsep dasar, Definisi, Ruang & Pemateri: Tim Pelaksana \\
\hline & biopori. & Lingkup, $\quad$ Dimensi, & Sasaran: Masyarakat Desa \\
\hline & & Karakteristik, & Puron \\
\hline & & Urgensi, dan Implementasi & Metode: \\
\hline & & & Tanya Jawab \\
\hline & & & Waktu: Sabtu (08.00-11.00) \\
\hline & & & $\begin{array}{l}\text { Alat: Papan edukasi, } \\
\text { handout, laptop }\end{array}$ \\
\hline \multirow{7}{*}{$\begin{array}{l}\text { Minggu } \\
\text { Ketiga }\end{array}$} & Fungsi dan manfaat & Konsep dasar, Definisi, Ruang & Pemateri: Tim Pelaksana \\
\hline & lubang resapan biopori & Lingkup, $\quad$ Dimensi, & Sasaran: Masyarakat Desa \\
\hline & & Karakteristik, & Puron \\
\hline & & Urgensi, dan Implementasi & Metode: Ceramah \\
\hline & & & Tanya Jawab \\
\hline & & & Waktu: Sabtu (08.00-11.00) \\
\hline & & & $\begin{array}{l}\text { Alat: Papan edukasi, } \\
\text { handout, laptop }\end{array}$ \\
\hline \multirow{7}{*}{$\begin{array}{l}\text { Minggu } \\
\text { Keempat }\end{array}$} & Penghijauan & Konsep dasar, Definisi, Ruang & Pemateri: Tim Pelaksana \\
\hline & kompos organik & Lingkup, & Sasaran: Masyarakat Desa \\
\hline & & Karakteristik, & Puron \\
\hline & & Urgensi, dan Implementasi & Metode: Ceramah \\
\hline & & & Tanya Jawab \\
\hline & & & Waktu: Sabtu (08.00-11.00) \\
\hline & & & Alat: Papan edukasi, \\
\hline
\end{tabular}

\section{Perancangan dan Pembuatan Teknologi Biopori}

Biopori adalah lubang terjadi karena adanya aktivitas organisme yang hidup didalam tanah. Namun karena berkurangnya lahan terbuka dan organisme yang hidup didalam tanah berkurang maka semakin berkurang juga jumlah biopori alami. Hal ini menyebabkan jumlah air hujan yang langsung masuk kedalam tanah semakin berkurang juga. Biopori buatan ini dibuat untuk menambah jumlah air yang terserap dalam tanah. Teknologi biopori telah dilakukan oleh beberapa peneliti, Kuruniastuti melakukan pengkajian tentang biopori yang mengadopsi teknologi biopori alam yang berada dikawasan lahan sempit dengan lubang resapan bekisar 10-30 cm dengan kedalaman $100 \mathrm{~cm}$ dan tidak melebihi permukaan tanah .(Karuniastuti, 2014)

Biopori merupakan teknologi sederhana tepat guna multi fungsi. Bisa untuk resapan air, bisa untuk mengurangi genangan air, bisa untuk wadah pengomposan, dan tentunya menyuburkan tanah. Selain itu juga teknologi ini sangat aplikatif karena mudah dan murah lebih sederhana daripada sumur resapan Kehadiran lubang resapan biopori secara langsung akan menambah bidang resapan air, setidaknya sebesar luas kolom/dinding lubang. Dengan adanya aktivitas fauna tanah pada lubang resapan maka biopori akan terbentuk dan senantiasa terpelihara keberadaannya (Suleman et al., 2018). Oleh karena itu, bidang resapan ini akan selalu terjaga kemampuannya dalam meresapkan air. Dengan demikian, kombinasi antara luas bidang resapan dengan kehadiran biopori secara bersama-sama akan meningkatkan kemampuan dalam meresapkan air. 
Jurnal SEMAR Vol. 9 No. 2, hal. $53-63$

eISSN: 2745-4223 | Copyright @ LPPM Universitas Sebelas Maret Homepage: https://jurnal.uns.ac.id/jurnal-semar

Perancangan dalam pembuatan teknologi lubang resapan biopori dapat dilihat pada Gambar 4 yang merupakan bentuk implementasi dari materi yang telah diberikan pada saat sosialisasi. Perancangan diimplementasikan untuk diterapkan di Desa Puron. Perancangan dilakukan bersama dengan masyarakat Desa Puron. Hal ini dilakukan juga sebagai upaya awal edukasi pada masyarakat mengenai penerapan teknologi biopori.

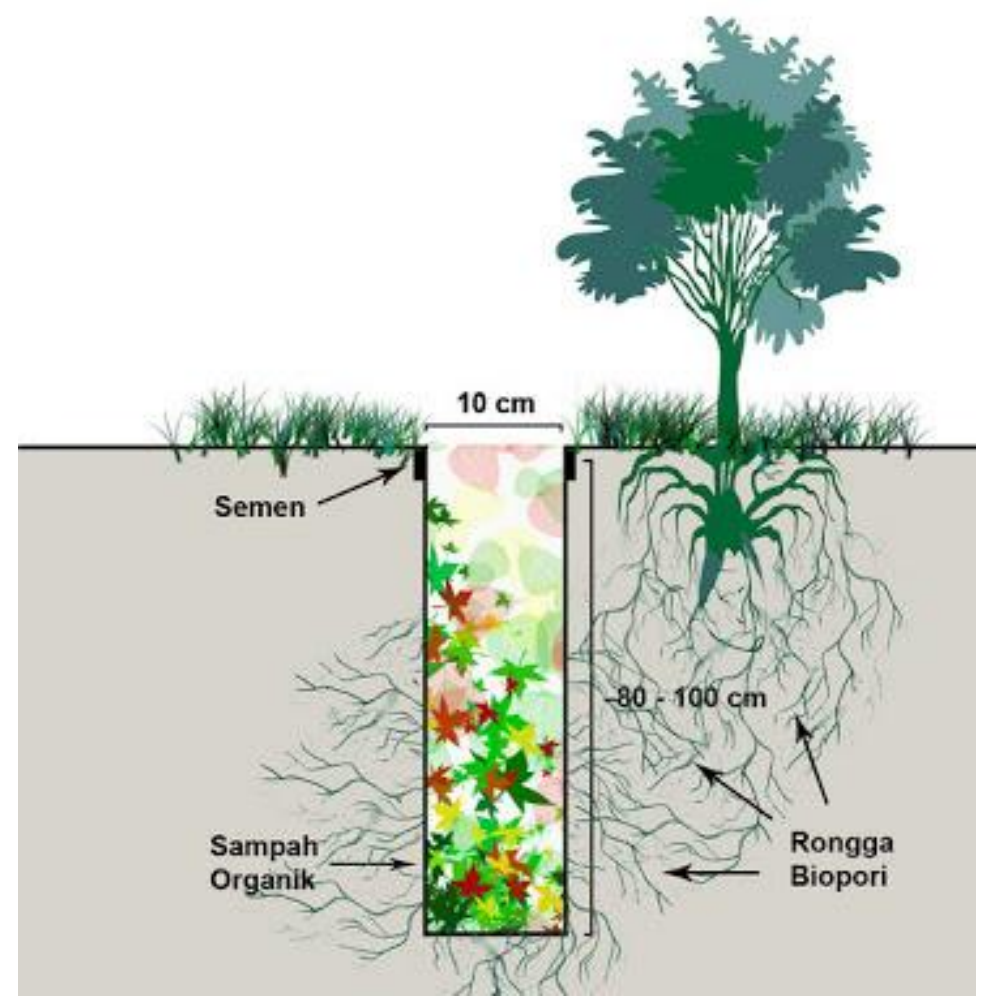

Gambar 4. Konsep lubang resapan biopori (Karuniastuti, 2014)

Setelah terbentuknya perencanaan, pengabdi dan mitra melakukan persiapan peyiapan alat dan bahan diantaranya: bor tanah, cangkul, golok, ember, gayung, bamboo, plengki, pipa PVC, kertas koran, sendok semen, semen, pasir, penutup bulat plastik, air, dan sampah organik. Perlengkapan alat dan bahan disediakan untuk dilakukan pelatihan pembuatan. Pelatihan pembuatan lubang resapan biopori mengikuti langkah-langkah berikut (Elsie et al., 2017).

1. Membuat lubang silindris di tanah dengan diameter 10-30 $\mathrm{cm}$ dan kedalaman 30-100 $\mathrm{cm}$ serta jarak antar lubang 50-100 cm.

2. Mulut lubang dapat dikuatkan dengan semen setebal $2 \mathrm{~cm}$ dan lebar 2-3-centimeter serta diberikan pengaman agar tidak ada anak kecil atau orang yang terperosok.

3. Lubang diisi dengan sampah organik seperti daun, sampah dapur, ranting pohon, sampah makanan dapur non kimia, dsb. Sampah dalam lubang akan menyusut sehingga perlu diisi kembali dan di akhir musim kemarau dapat dikuras sebagai pupuk kompos alami. 
Jurnal SEMAR Vol. 9 No. 2, hal. $53-63$

eISSN: 2745-4223 | Copyright (C LPPM Universitas Sebelas Maret Homepage: https://jurnal.uns.ac.id/jurnal-semar

4. Pupuk kompos yang terbentuk dalam lubang resapan berfungsi menyuburkan tanaman.

5. Untuk memperkuat dinding lubang tidak longsor, pangkal lubang perlu dibuat penahan dengan membuat adukan semen selebar $2-3 \mathrm{~cm}$ dan setebal $2 \mathrm{~cm}$ di sekeliling lubang.

6. Jumlah lubang resapan biopori ditentukan berdasarkan luas lahan. Setiap $50 \mathrm{~m} 2$ luas lahan dibuat 10 lubang.

Pelatihan pembuatan teknologi biopori dilakukan untuk menambah pengalaman yang diberikan pada masyarakat. Sehingga masyarakat lebih paham dan menambahnya pengetahuan mengenai pembuatan lubang resapan biopori secara mandiri. Setelah pelatihan dilakukan, selanjutnya pembuatan lubang resapan bioprori dilakukan di titik titik yang sudah dipetakan, pembuatan di lahan kosong yang terdapat sampah organik dari daun kering sebagaimana Gambar 5.

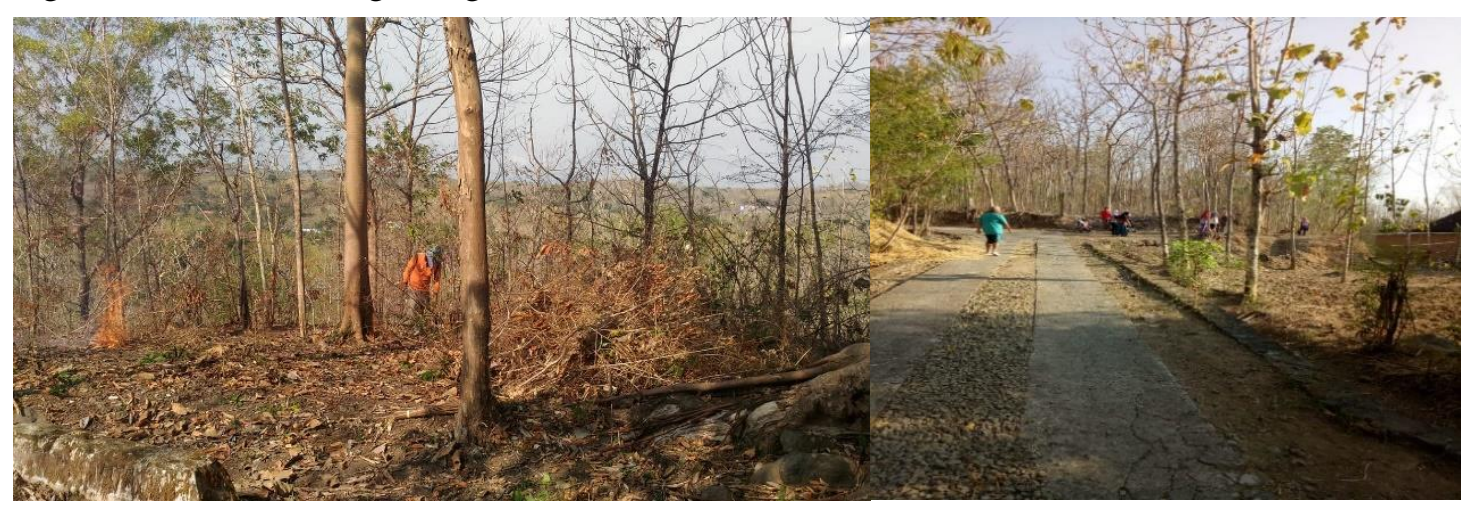

Gambar 5. Titik tempat pembuatan lubang resapan biopori

Pengabdi dan mitra yaitu masyrakat Desa Puron secara bergotong-royong melakukan pembersihan lingkungan dan pembuatan lubang resapan biopori, sebagaimana Gambar 6. Hasil sosialisasi dan pelatihan dilakukan penerapan langsung pembuatan lubang resapan biopori melalui tahapan-tahapan sesuai yang telah dipaparkan. Pembuatan lubang resapan biopori telah berhasil dilakukan dengan sistem bertahap ke setiap titik yang telah dipetakan. Respon masyarakat sangat aktif dan antusias. Masyarakat berterimakasih karena pengabdi mau berkontribusi dalam penanggulangan masalah mengeringnya tumbuhan yang disebabkan karena sedikitnya ketersedian air dan penanggulangan sampah organik. 


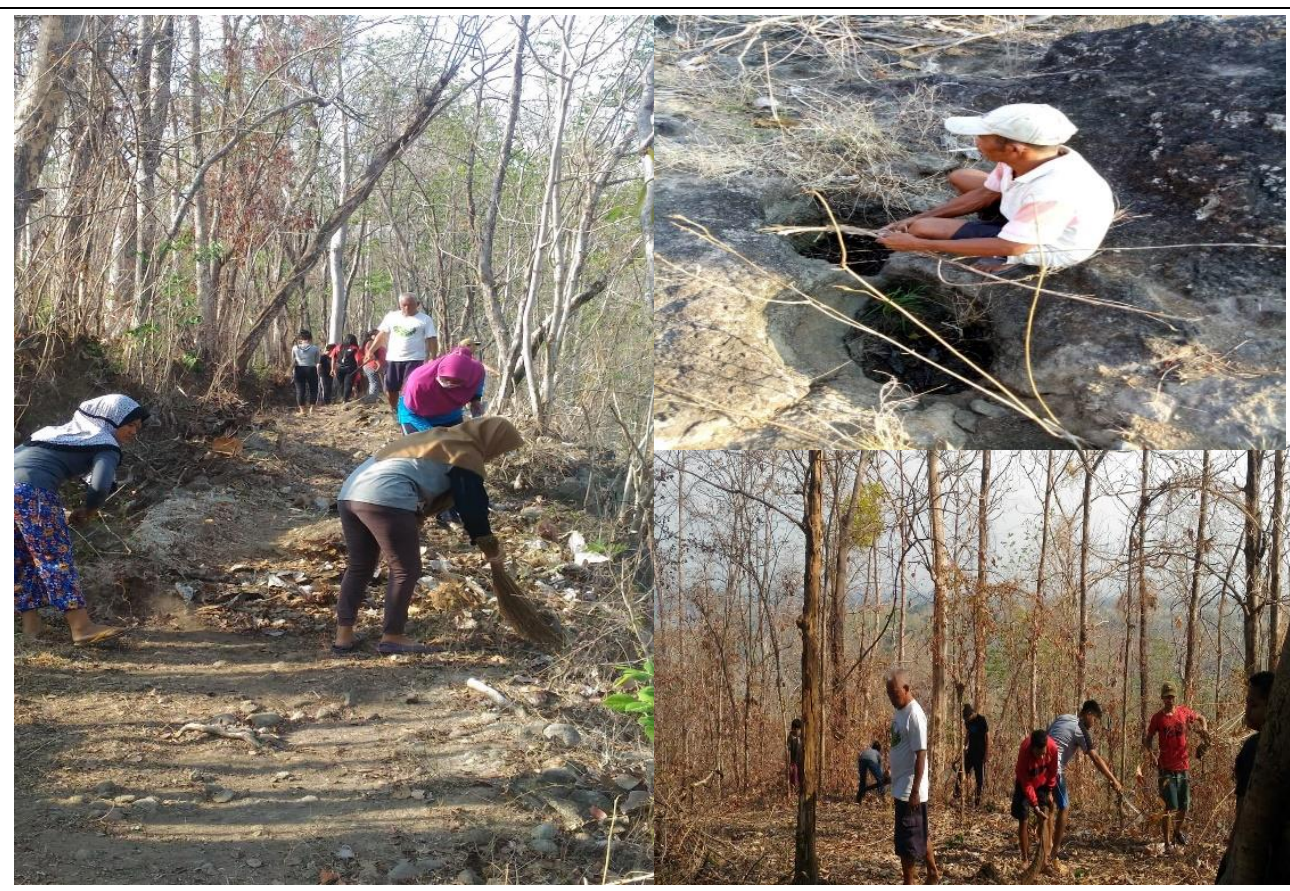

Gambar 6. Pelaksanaan pembuatan lubang resapan biopori

\section{Monitoring dan Evaluasi Kegiatan}

Hasil pelaksanaan kegiatan pengabdian masyarakat yang telah dilakukan di Desa Puron, Kecamatan Bulu, Kabupaten Sukoharjo, dapat dikatakan berjalan dengan baik dan lancar. Adanya koordinasi, kerjasama, dan pelibatan masyarakat Masyarakat telah menjadikan kegiatan pengabdian ini berjalan dengan sukses dan telah memberikan sumbangsih serta manfaat yang positif bagi warga setempat, khususnya dalam transfer pengetahuan dan keterampilan membuat lubang resapan biopori di lingkungan Desa Puron sebagai solusi ketersediaan air agar tidak mengeringnya tumbahan dan penanggulangan sampah oranik. Antusiasme dan sambutan hangat dari kegiatan sangat baik dan masyarakat juga mendukung adanya kegiatan pengabdian masyarakat di lingkungan mereka. Mengingat kawasan tersebut ketersedian air menurun sehinggan tumbuhan mengering.

Proses pelaksanaan kegiatan pengabdian masyarakat ini pada umumnya berjalan dengan baik dan lancar. Komunikasi, koordinasi, dan kerjasama dengan pihak-pihak terlibat berlangsung dengan sukses dan kooperatif. Pada kegiatan survei, observasi, dan pengamatan lokasi kegiatan, dalam hal ini di Desa Puron telah memenuhi kriteria dan kesesuaian atas isu kegiatan yang diangkat, sehingga penentuan lokasi kegiatan yang dipilih sudah tepat dan sesuai dengan ruang lingkupnya. Sementara pada kegiatan sosialisasi dan bimbingan teknis pembuatan lubang resapan biopori yang telah dilakukan juga berjalan dengan baik dan lancar. Partisipasi dan pelibatan masyarakat berjalan dengan kooperatif dan adanya peningkatan pengetahuan dan keterampilan peserta selama proses kegiatan berlangsung. Proses inti dari pelaksanaan kegiatan pengabdian masyarakat ini adalah pembuatan lubang resapan biopori di titik rawan kekeringan. Pada umumnya proses kegiatan ini berjalan dengan sukses dan lubang resapan biopori sebagai media penyerap air hujan berfungsi sebagaimana mestinya. Hal ini telah dipantau juga 
Jurnal SEMAR Vol. 9 No. 2, hal. $53-63$

eISSN: 2745-4223 | Copyright (C LPPM Universitas Sebelas Maret Homepage: https://jurnal.uns.ac.id/jurnal-semar

pada tahapan kegiatan monitoring dan evaluasi selama proses pelaksanaan dan setelah pelaksanaan kegiatan. Hasil monitoring bahwa lubang resapan biopori bermanfaat untuk penyerapan air hujan sehingga adanya ketersediaan air (Safitri et al., 2019). Hal itu ditandai dengan tumbuhan pada lingkungan yang terdapat lubang resapan biopori menjadi berdaun lebat dan hijau, sebagaimana Gambar 7.

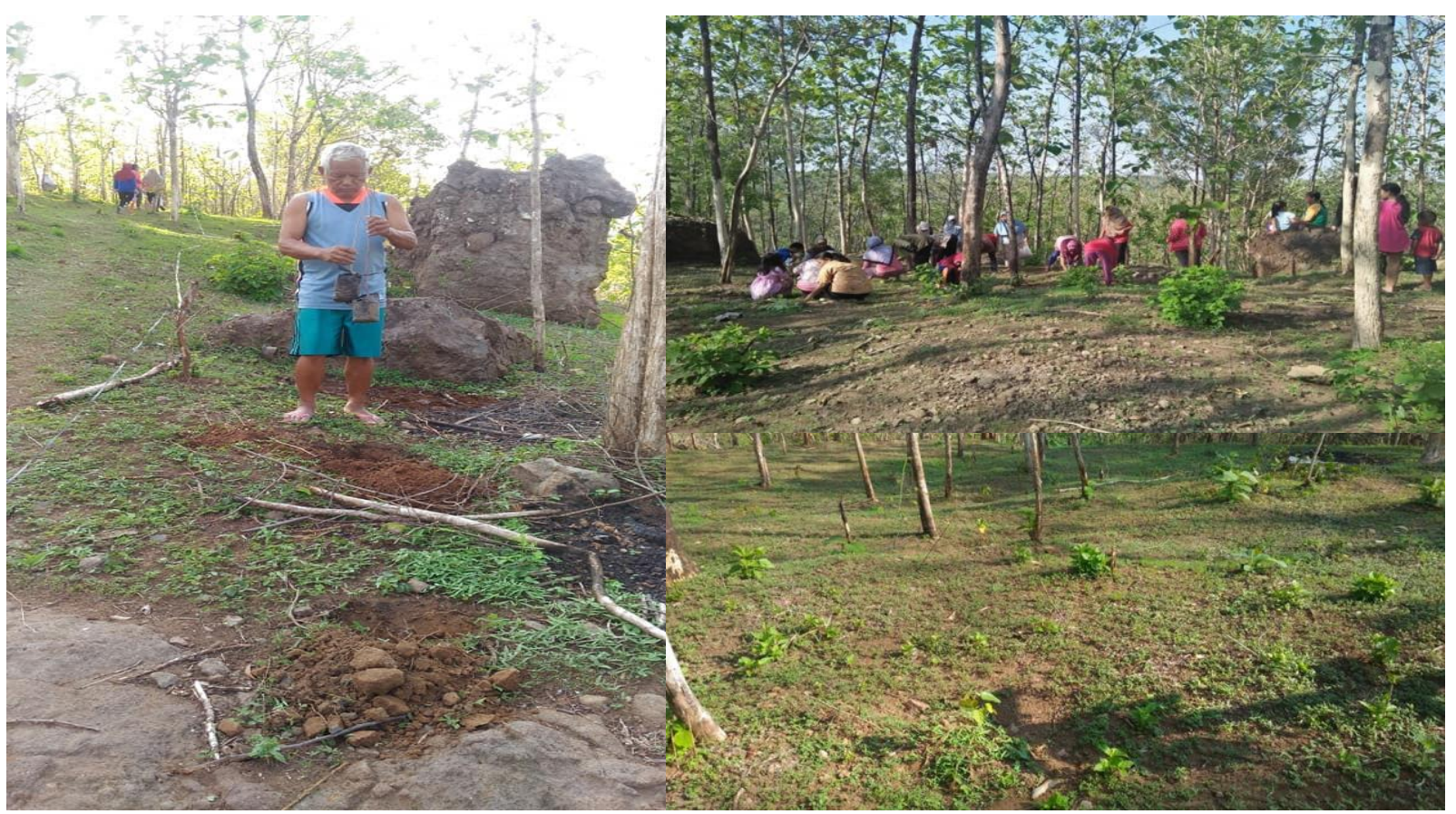

Gambar 7. Hasil lubang resapan biopori

Pelaksanaan kegiatan pengabdian masyarakat ini tentunya terdapat beberapa hambatan dan tantangan di dalam proses perencanaan, penyusunan, dan pelaksanaannya. Beberapa hambatan dan tantangan yang ditemui selama pelaksanaan kegiatan masih bisa diselesaikan dengan baik pada saat pelaksanaan berlangsung. Berikut ini adalah beberapa hambatan dan tantangan yang muncul selama pelaksanaan kegiatan, diantaranya sebagai berikut: 1) Alat bor biopori yang tidak tersedia, sehingga harus didesain dan dibuat terlebih dahulu dan memerlukan waktu yang cukup lama; 2) Karakteristik tanah di lokasi kegiatan yang banyak terdapat batuan kapur dan 3) Cuaca yang kurang mendukung pada saat pelaksanaan kegiatan.

\section{Kesimpulan}

Program kemitraan masyarakat dalam bentuk pengabdian melalui penerapan teknologi biopori pada masyarakat Desa Puron, Bulu, Sukoharjo, Jawa Tengah telah berhasil dilakukan. Hal itu tercermin pada tingkat antusias dan ketertarikan terhadap pembuatan lubang resapan biopori dan mampunya masyarakat dalam menerapkan konsep tersebut secara mandiri. Penerapan teknologi biopori merupakan program pengabdian yang dapat memecahkan masalah ketersedian air dan sampah organik dilingkungan 
sekitar. Biopori berfungsi sebagai lubang resapan air sehingga air memiliki cadangan air dan mengurangi dari permasalahan akan banjir juga menyuburkan dari tanah. Hal ini ditandai dengan menghijaunya kembali tumbuhan di lingkungan sekitar pelaksanaan program.

\section{Ucapan Terima Kasih}

Penulis mengucapkan terima kasih kepada Rektor Universitas Sebelas Maret melalui Dana PNBP dengan kontrak No: 453/UN27.21/PN/2020 dan Paguyuban Pecinta Lingkungan Hidup Desa Puron dalam mendukung Program Kemitraan Masyarakat Tahun 2020.

\section{Daftar Pustaka}

Bank, P., Di, S., Puron, K. D., Astuti, D., Muharram, J. U. and Listiana, Y. (2016) 'Pembentukan Bank Sampah Di Kebayanan-i Desa Puron Kecamatan Bulu Kabupaten Sukoharjo'.

Elsie, E., Harahap, I., Herlina, N., Badrun, Y. and Gesriantuti, N. (2017) 'Pembuatan Lubang Resapan Biopori Sebagai Alternatif Penanggulangan Banjir Di Kelurahan Maharatu Kecamatan Marpoyan Damai Pekanbaru'. Jurnal Pengabdian UntukMu NegeRI, Vol. 1, No. 2, pp. 93-97.

Karuniastuti, N. (2014) 'Teknologi Biopori Untuk Mengurangi Banjir Dan Tumpukan Sampah Organik'. Jurnal Forum Teknologi, Vol. 04, No. 2, p. 64.

Kusumawati, H., Keguruan, F., Ilmu, D. A. N. and Surakarta, U. M. (2008) 'Dengan Ketersediaan Air Tanah Di Kecamatan Jaten'.

Mulyono, A. (2014) 'Pengetahuan Geografis Dan Pengetahuan Geografis Dan Kesiapsiagaan Masyarakat Di Kecamatan Bulu Kabupaten Sukoharjo Dalam Menghadapi Bencana Gempa Bumi'.

Permana, E., Lisma, A., Lestari, I. and Putra, A. J. (2019) 'Penyuluhan Pembuatan Biopori Sebagai Lubang Resapan Di RT 04 Kelurahan Mayang Mangurai Kota Jambi'. Jurnal Paradharma, Vol. 3, No. 2, pp. 129-134.

Safitri, R., Purisari, R. and Mashudi, M. (2019) 'Pembuatan Biopori Dan Sumur Resapan Untuk Mengatasi Kekurangan Air Tanah Di Perumahan Villa Mutiara, Tangerang Selatan ( The Implementation of Bio Pores and Infiltration Wells to Resolve the Lack of Groundwater in the Villa Mutiara Housing, South Tanger'., Vol. 5, No. 1.

Sedana, D., As'ari, A. and Tanauma, A. (2015) 'Pemetaan Akuifer Air Tanah Di Jalan Ringroad Kelurahan Malendeng Dengan Menggunakan Metode Geolistrik Tahanan Jenis'. Jurnal Ilmiah Sains, Vol. 15, No. 1, p. 33.

Sinaga, R. (2008) 'Air Pada Rumput Gajah Dan Rumput Raja Akibat Penurunan Ketersediaan Air'. Jurnal Biologi Sumatera, Vol. 3, No. 1, pp. 29-35.

Suleman, A. R., Bustan, B., Erdiansa, A., Jurusan, D., Sipil, T., Negeri, P. and Pandang, U. (2018) 'Pembuatan Lubang Resapan Biopori Sebagai Resapan Banjir Pada Daerah Genangan Di Kelurahan Buntusu Kota Makassar’. Prosiding Seminar Hasil Pengabdian (SNP2M), Vol. 2018, No. 2016, pp. 169-174.

Widyastuty, A. A. S. A., Adnan, A. H. and Atrabina, N. A. (2019) 'Pengolahan Sampah Melalui Komposter Dan Biopori Di Desa Sedapurklagen Benjeng Gresik’. Abadimas Adi Buana, Vol. 03, No. 1, pp. 21-32.

Yohana, C., Griandini, D. and Muzambeq, S. (2017) 'Penerapan Pembuatan Teknik Lubang Biopori Resapan Sebagai Upaya Pengendalian Banjir’. Jurnal Pemberdayaan Masyarakat Madani (JPMM), Vol. 1, No. 2, pp. 296-308. 